\title{
MARRIAGE AND RITUAL AMONG THE ATA BAOLANGU OF LEMBATA, EASTERN INDONESIA: MEANINGS, PRACTICES AND CONTEXTS
}

\author{
Justin L. Wejak* \\ Indonesian Studies, Asia Institute, University of Melbourne, \\ VIC 3010, Australia \\ E-mail: justinw@unimelb.edu.au
}

Published online: 15 July 2020

To cite this article: Wejak, J. L. 2020. Marriage and ritual among the Ata Baolangu of Lembata, Eastern Indonesia: Meanings, practices and contexts. International Journal of Asia Pacific Studies 16 (2): 29-57. https://doi.org/10.21315/ijaps2020.16.2.3

To link to this article: https://doi.org/10.21315/ijaps2020.16.2.3

\begin{abstract}
This paper explores the meanings, practices and contexts of marriage and ritual among the Ata Baolangu of Lembata, Eastern Indonesia. Using the methodology of qualitative field research conducted by interviewing local stakeholders and by both participation in, and observation of, local community life, the paper proposes that all of the marriage rituals are necessary to ensure a legitimate relationship between the two parties involved and that procreation is necessary to maintain and transform social relations between and within clans, and to create harmony between the two worlds - of the living and the dead. This proposition is explained throughout the paper by first examining the concepts of marriage and ritual, followed by analysis of the stages of the rites and their meanings. By including some further reflection beyond ethnological boundaries, the paper hopes to contribute to a broader understanding of, and discourse on, the theme of traditions and philosophies in Asia. An endeavour to preserve traditions of marriage and ritual are philosophically necessary for the future prosperity of family and society, social structure and relations, as well as to give a sense of meaning, belonging and identity.
\end{abstract}

Keywords: Marriage, ritual, belis, brideprice, adat 


\section{INTRODUCTION}

As reflected in the title, this paper examines the meanings, practices and contexts of marriage and ritual among the Ata Baolangu of Lembata, Eastern Indonesia. Indeed, there is a fundamental correlation between marriage and ritual. Marriage is fundamentally related to ritual; no rituals, no marriage. Marriage rituals are related to fertility, procreation and legitimisation. They are also about "feeding" (local language of Baolangu: paraw boi) the community of the living and the dead - actually and symbolically — as a symbol of peace and relationship, acceptance and legitimisation. The community studied is located in the interior of Lembata, an island situated in the northeast of the island of Flores. ${ }^{1}$ Economically, the majority of villagers gain their livelihood from dry-field cultivation, with a smaller number employed in teaching and local government. The farmers in Baolangu (culturally, comprising three main villages namely Lewokukung, Lite/Ulumado and Namaweka/ Nubamado) grow rice, corn, tapioca, sweet potato, candle nut, coconut, chocolate, cashew nut, vegetables, fruit, as well as coffee and tobacco. The main religion adhered to by the majority of the villagers and the people of Lembata is Catholicism. Despite the conversion of many Lembatanese to Catholicism since the arrival of the Portuguese in the early 16th century in their quest for eastern Indonesia's precious spices and sandalwood, it should be noted that their indigenous religion based on adat (customary law) has been maintained to this day. According to Müller (1997), people who reside in coastal areas of Lembata are mainly Muslims, and those who live in the interior of the island are mainly Catholics and followers of, in the words of Müller, "the old animist faith or the primordial religion" (Müller 1997: 149). Yogi Making (2013) also notes that most people residing in the interior of the island, locally known as ata kiwan, embrace Catholicism. Whereas their coastal counterparts, ata watan, are primarily Islamic. Despite their religious and ethnic differences, the people of Lembata have generally lived side by side harmoniously. They have cooperated, for example, in building churches and mosques, and in creating a peaceful atmosphere for religious celebrations such as Christmas, Easter, Ramadhan and Idul Fit'ri. ${ }^{2}$

Methodologically, the findings discussed in this paper are the result of field research conducted by interviewing local stakeholders, ${ }^{3}$ and through participation in, and observation of, local community life. Both methods enabled me to observe and analyse local ideas of ritual, marriage and the family. ${ }^{4}$ A key reason for conducting the field research in the community of the Ata Baolangu then was that, despite providing fertile ground for the 
study of marriage and ritual, this community is yet to be the subject of any published research. I should note, however, that in 1998, I wrote a minor thesis for a Post-graduate Diploma in Arts (Anthropology) at the University of Melbourne entitled, "The Mythical Origins and Meanings of Sacrificial Rituals of the Rice Mother in Flores, Eastern Indonesia," in which I argued that "rice rituals in Flores are examples of the general class of sacrificial rituals" (Wejak 1998: 1). ${ }^{5}$ In 2001, I completed a major thesis for my Master at the same university on the idea of status and power in marriage rituals among the Ata Baolangu of Lembata, Eastern Indonesia. In this paper, I present some of the findings from that research as well as elaborations on it in view of subsequent developments.

Even though the marriage rituals of the Ata Baolangu are characterised by a combination of customary marriage and the Catholic sacrament of matrimony, this paper focuses more on the customary aspects of marriage rituals. It argues that the customary marriage rituals have many functions, namely to legitimise the relationship between the couple, to ensure legitimate procreation, to maintain and transform social relations between and within clans, and to create harmony between the two worlds (of the living and the dead). Through such rituals the community asks for the legitimisation of the union in the eyes of the adat community. The customary marriage rituals are also a way to acknowledge the importance of the relationship between the profane world of the living and the sacred, namely the ancestral spirits and the Lamaholot God-Lera Wulan Tana Ekan ${ }^{6}$ - as well as to strengthen the relationship between the wife-giving and wife-receiving clans. A marriage is not considered successful until at least one offspring is produced from it. A childless marriage is regarded as a curse from God or the ancestral spirits, by way of the opo puk, the bride's mother's brother (bride's maternal uncle) and the grandmothers' brothers (maternal great uncles) of the bride and bridegroom. Marriage rituals thus pertain to relations not just among individuals but also among clans.

The primary purpose of this paper is thus to explore the customary marriage rituals of the Ata Baolangu with a particular focus on identifying the stages of rites and explaining the symbolic meanings of the rituals. Ritual is an intrinsic part of social life. In Ata Baolangu, marriage rituals can be a golden opportunity for adat leaders, including the opo puk and the clan heads, to assert their power. Such community figures may exploit certain rites, such as those concerning marriage, to recreate a particular social reality for the people around them. Through participation in these rites, the people identify with larger social forces that can only be made visible in symbolic forms. 
Through participating in marriage rituals, for instance, one may have some idea of what is going on in the society, for, as David Kertzer puts it, "we live in a world that must be drastically simplified if it is to be understood at all" (Kertzer 1988: 2). The paper also examines the indigenous concept of marriage, in which marriage is viewed as a human reality closely associated with procreation. James Fox's term "flow of life" (Fox 1980a) is useful to describe what this implies in the adat context. In Catholic theology, as stated in the Bible, marriage is associated with a divine plan to populate the earth (Genesis 1: 27-28).

It should be noted, even though this paper uses the indigenous community of the Ata Baolangu as a case in point, it should not be seen as an ethnographic study of customary marriage rituals per se. Rather, the study supports the four general points that I explain in the paper. First, the paper demonstrates how ritual functions as an intrinsic part of social life as seen in the marriage customs of the people of Ata Baolangu. Second, the paper supports the notion that marriage in Ata Baolangu are not just individual but also (and more importantly) clan arrangements. Third, it highlights that customary marriage of the Ata Baolangu incorporates and is in accord with Catholic understandings about marriage as procreation. Fourth, the study posits the proposition that marriage rituals are perceived as necessary in ensuring a legitimate relationship between the two parties involved and legitimate procreation, in maintaining and transforming social relations between and within clans, and in creating harmony between the two worlds - of the living and of the dead. Attempts to formulate particular concepts concerning marriage may involve an investigation of the local adat organisation, the process of customary marriage, and the indigenous views on marriage. It is also hoped that this work will encourage others to revisit and reformulate the concept of marriage in reference to Southeast Asia. For the people of Lembata in general, and the people of Baolangu in particular, it is hoped that this study may increase appreciation of the richness of their culture and the constitution of their social identity through rituals, particularly concerning marriage.

Having explained these, in the next few pages I shall examine the two key concepts of marriage and ritual. I shall first explain the meanings of ritual to provide some context for my analysis of customary marriage rituals practised among the Ata Baolangu of Lembata. 


\section{What Is Ritual?}

Most ritual theorists seem to agree that rituals involve different purposes and actions. For instance, in Christian rituals, the act of receiving bread and wine during the Holy Communion is different from eating bread and drinking wine at any other time. The question is, how is this difference constructed? Barnard and Spencer argue that "the difference relates to the meaning attached to the ritual act, which is suggested by the use of symbols" (Barnard and Spencer 2000: 490). It is the system of meaning, through the use of a set of ritual symbols, that constructs the difference between eating bread and drinking wine at these different occasions. Thus, semantically, for an act to be considered a ritual, or a ritualised act, there must be a purpose or meaning beyond that of the act in itself. In this sense, ritual actions should always be understood and analysed within a system of meaning and symbolism.

David Kertzer, in paraphrasing Clifford Geertz's (1973) definition of culture, defines ritual as "action wrapped in a web of symbolism" (Kertzer 1988: 9). This definition of ritual implies its communicative element or role. There is assumed to be something beyond: a purpose, a function and a meaning, which is communicated in and through ritual action. Such an intrinsic relationship between ritual action and its purpose, function and meaning is undeniable. The British functionalist anthropologists of the 1950s and the 1960s, who took their lead from Emile Durkheim, have also emphasised the integrative function of ritual. Durkheim argued that "because the apparent function of ritual is to strengthen the bonds attaching the believer to god, and god is no more than a figurative expression of society itself, so ritual in fact serves to attach the individual to society" (Durkheim 1976 [1912]: 226). It can be said that ritual discourse is a specific representation of society. In this sense, the study of its rituals offers revealing insights into how a given society is conceptualised by its members. As noted by Barnard and Spencer, "ritual is habitually connected to a sacred tradition" (Barnard and Spencer 2000: 490). This has led to "the synchronic pursuit of an inevitable and generalised ritual form which also implies a generalised ritual function. Attempts to define this function have generally seen ritual as either supporting social structure by directly representing it, or legitimising social authority by concealing it" (Barnard and Spencer 2000: 490). Thus, according to Barnard and Spencer, "ritual's social role is either to bolster, or conceal, the prevailing political order" (Barnard and Spencer 2000: 490). 
Societies are indeed largely constructed on, and characterised by, rituals. It is impossible to imagine a society without rituals. A society is shaped by rituals, and rituals strengthen a sense of communitas (Turner 1969). Daniel de Coppet also states that "rituals are at the core of the social identity of all communities" (de Coppet 1992: 1). The coexistence of societies and rituals are undeniable (Durkheim 1976 [1912]). In the context of the Ata Baolangu, there are many different rituals practised by the community, including birth rituals, rites of initiation, marriage rituals, rites of the dead and agricultural rituals. The Ata Baolangu views rituals as an essential element in their everyday lives, with rituals always thought of as being associated with land or social relations such as marriage and harmony. In the following section, I shall explain the meanings of marriage.

\section{What is Marriage?}

Marriage can be defined as "a legal union between a man and a woman as husband and wife, state of being married, ceremony at which a couple are married, wedding" (Cowie 1989: 762). Sociologically, marriage is "a sexual union, the structure of which varies considerably according to general social conditions" (David, cited in Rahner 1986: 905). Modern fieldwork in anthropology rebuts the 19th century evolutionary theories to the effect that marriage gradually developed from primitive promiscuity through various stages of group marriage namely sexual relations of all the men with all the women in a group, and polygamy to monogamy. The view of monogamy, as the apex of a process of evolution, may be historically linked to the Catholic Church's definition of marriage as "a life-long, indissoluble union between one man and one woman" (David, cited in Rahner 1986: 905).

Monogamous marriage, however, is very widespread indeed and associated with no particular form of culture. Furthermore, polygamous marriage, especially the practice of polygyny which means "a man can have more than one wife at the same time" (Zonabend, cited in Barnard and Spencer 2000: 351), is favoured in complex social conditions where there is a particular demand for female workers, or where prestige in, and the desire for, numerous offspring is involved. In the community of the Ata Baolangu today, there is no polygamy but, according to a local oral tradition of genealogy, polygamy was practised in the past generations. This suggests that monogamy as practised today in the agrarian Catholic society of the Ata Baolangu was once a foreign concept prior to Catholic missionary activity in the region around the 19 th century. 
Like many other residents of the Indonesian archipelago, the people of Ata Baolangu strongly identify marriage with procreation. Marriage is almost synonymous with producing children, not only one or two but as many as one can afford. Having children symbolises fertility, vitality and continuity, or in James Fox's terms, a "flow of life" (Fox 1980a). This "flow of life" is not just a personal but a social concern; it is the responsibility and for the benefit of the Lewotana or the Lewuenaj. ${ }^{8}$ The concepts of marriage and procreation are inseparable. It is a common belief that every individual member of a clan must get married one day and have children because having children is essential for the continuity of the community. One of my interviewees, Bala-Kwasa once said, "The bigger a clan the better because it brings good fortune for that clan" (Bala-Kwasa, interview, July 2000).

It is important to note that individual members of the society today, despite economic hardship, do not seem to challenge the constructed identification of marriage with procreation. In my view, the most likely reasons for this are as follows: first, the business of marriage and procreation is more a family concern and responsibility. Rather than an individual business between two persons, it is a clan matter; a social event. Secondly, in traditional agricultural societies, including the Ata Baolangu, marriage can upgrade and improve one's social status within the society. Thirdly, having many children can help parents to work their farms and look after the nura newa (agricultural land). There is a saying in Indonesian: "Banyak anak, banyak rezeki" (literally, many children, much fortune), and this saying reaffirms the association of marriage with reproduction and economy. To be married is to reproduce, not just one but many, partly for agricultural purposes in agrarian communities such as the Ata Baolangu. Finally, changes in traditions are still considered by the Ata Baolangu as violating the tradition of the ancestors; and this is regarded as a kind of rebellion that needs to be avoided. Thus, the young people in the village are always taught, especially by their parents and relatives, to follow their traditions, their adat. This fear of change is probably complicated by many factors including limited knowledge and education, and to a certain extent, ambivalence towards modernity, which can be perceived as dangerous to a harmonious and stable social life and identity.

As noted, the business of marriage among the Ata Baolangu has little to do with individual choices; it is more a social or family matter. The family recommends who one should marry, and criticises couples when they cannot see signs of pregnancy. The following story, described to me by a young man in the village, is perhaps a good illustration of the idea of an arranged marriage as it is still practised in the village today. The young man recounted how his 
family suggested he should consider marrying a certain girl in the village. The young man said nothing, but only smiled. Sometimes he replied, "I don't know." They then said, "you are both very compatible." This indigenous concept of a couple's compatibility is worth examining, as it is related to the idea of exogamous marriage and rotation of brideprice (ivory tusks) from one clan to another within the same village community, as well as (more importantly) the couple's suitability for the purpose of reproduction.

The institution of marriage has been defined by scholars as "the union of man and woman, and children who are born from that union are recognised as legitimate" (Zonabend, cited in Barnard and Spencer 2000: 350). This definition has attracted further anthropological debate and research, usually in the context of studies of the family. Claude Levi-Strauss was perhaps the most impressive contributor to the development of this field. According to Levi-Strauss, marriage alliance is at the very heart of kinship; and marriage as a structure of exchange within a kinship system prohibits incest (Zonabend, in Barnard and Spencer 2000: 350). Among the Ata Baolangu, incest is indeed not only prohibited but also punishable. Those who commit incest are exiled from the village. There was at least one case that I know of where an incestuous couple (siblings) were exiled from the village to Ende in central Flores. They have never returned to the village since the late 1970s, but their children have visited their extended family in the village of Lewokukung (Baolangu), though only recently in the late 2000 s. ${ }^{10}$

The incest prohibition requires the avoidance of unions between close (blood) relations. The institutionalisation of the prohibition of incest, in my view, can be identified as both a form of institutionally stabilising exogamy and destabilising endogamy. Exogamy means one must find "a marriage partner outside the close family group" (Zonabend, in Barnard and Spencer 2000: 350); and among the Ata Baolangu, exogamy is strictly enforced. It is stated that "endogamy demands or recommends marriage within a prescribed group or locale" (Zonabend, cited in Barnard and Spencer 2000: 350); and in the belief of the Ata Baolangu, such endogamy is a form of incest and is strictly banned because incest destabilises the structure of exchange and reciprocity. The prohibition of incest is probably perceived positively as it leads to exogamy, which implies marriage with others, and this exogamy is valued because it produces exchange and reciprocity (Levi-Strauss 1969 [1949]). Moreover, children born from an exogamous marriage are locally considered smei alus, literally "good blood," which means that the children are born from a true (approved) union. The Ata Baolangu believe that endogamous marriage is a form of incest, which leads to a curse, and damages kinship relations. 
A child born from an endogamous marriage is locally considered, smei kdatek, which literally means "bad blood" or anak haram, forbidden child.

Furthermore, as noted by Barnard and Spencer (2000), marriage is seen not only as an opportunity to recreate social relationships, but is also often accompanied by prestations both symbolically and materially. The idea of exchange and reciprocity establishes the marriage and sets up long-lasting relationships between the two clans who engage in the business of marriage. In Ata Baolangu, the family of the bridegroom must give to the family of the bride marriage payments or bridewealth including elephant tusks (witi bala), and the bride's family must give something back in return, typically including traditional sarongs, bracelets and clothes. Barnard and Spencer claim that this "structure of marriage prestations can have important political, economic, and ritual consequences for the society as a whole" (Barnard and Spencer 2000: 351).

Concerning bridewealth, my interviewee Magi-Kodan once said: "In principle, the greater the ivory in terms of quantity and quality, the greater the prestige enjoyed by family and clan" (Magi-Kodan, interview, July 2000). Magi-Kodan went on to say: "The wife-giving clan, in demanding brideprice, should also consider the social and economic capability of the wife-receiving clan, and their capacity to reciprocate" (Magi-Kodan, interview, July 2000). This is important because such an ethos of reciprocity limits the possibility of interpreting bridewealth negotiations as a matter of simple profit maximisation. The more one receives the more one should give in return. Giving and receiving in the context of customary marriage rituals among the Ata Baolangu is an obligation. Everyone is involved in the business, they are obliged to give and receive. A French sociologist, Marcel Mauss (18721950), explained the idea of reciprocity and gift exchange in a short book titled The Gift, first published in French in $1925 .{ }^{11}$ According to Mauss, as experienced in human history gifts are never truly free; they are always meant to be reciprocal, and reciprocity - giving and receiving - is like an obligation. There is an obligation to give, to receive and to reciprocate. Morally, to give is to receive, and to receive is to reciprocate. This reciprocal exchange is the core element in Mauss's theory on gifts. At the spiritual level, both the giver and receiver do not simply exchange gifts, but also (and more so) exchange part of themselves. There is therefore no separtation between objects exchanged and the people themselves (Mauss 1993; Douglas 1993). Socially, because of the bond between giver-receiver and gift, the act of giving and receiving creates a strong social bond between and amongst the people. 
In the context of brideprice among the Ata Baolangu, the two marrying families - the man's and the wife's - are engaged in the exchange of "gifts": the man's family gives an ivory tusk, and the woman's family gives for example traditional sarongs, ivory bracelets and clothes to the man's family in return. A local respondent from the Ata Baolangu community, in a conversation dated 6 December 2018, explained to me that in Baolangu there are two types of ivory tusks (locally called bala) —Bala Tmawil and Bala Oeng - given by the man's family to the woman's family. According to the same respondent, Bala Tmawil must be reciprocated immediately when receiving it, but if it is Bala Oeng then the reciprocation can be delayed. In the local language of Baolangu, the respondent says:

Opo alap mesti ya poena bala tmawil mesik, kalo take bine maki ya gutena bala yae tuenga. Tapi kalo dede bala oeng, maka balaru de bisa ya gutena eni kia, bene lejo puje nepe opo alap ya peten bine maki untuk ya balasa bala oeng dede (local respondent, 6 December 2018). ${ }^{12}$

The citation above highlights the very idea of marriage as a system of exchange, a system of giving and receiving, a system of reciprocity. This reciprocal aspect of marriage is widespread, and can be seen in many other communities elsewhere.

Having discussed the meanings of ritual and marriage, I shall now move on to exploring the stages of customary marriage rituals among the Ata Baolangu. I identify three key stages: the ritual of gewi una (literally, the entering of the bride's family home), the ritual of sera kiri blino malu kleruk (the traditional formalisation of marriage), and the negotiation ritual of brideprice.

\section{The Key Stages of Customary Marriage Rituals}

The indigenous customary marriage rituals among the Ata Baolangu begin with the ritual of gewi una (entering the woman's family home), followed by the ritual of sera kiri blino malu kleruk (the traditional formalisation of marriage), and the negotiation ritual of brideprice. All of these three rites must be completed as they are, as argued, necessary means to ensure legitimate relationship between the two parties involved, to ensure procreation, the maintenance and transformation of social relations between and within clans, and to ensure the creation of harmony between the two worlds - of the living and the dead. During the rituals, all clan members must gather together to 
represent a socio-cosmic bond between the worlds of the living and the dead. The clan heads, in particular, play a very influential role in the whole ritual process to ensure that the process is legitimate according to their local adat.

\section{The Gewi Una Ritual}

The word gewi means "to enter"; and una means "house, home." The purpose of the gewi una ritual is for the man's family members to introduce themselves to the woman's family. This is the first formal stage of marriage in Ata Baolangu, and is not a marriage proposal. Essentially it involves the man's family, through their delegates, asking for approval from the woman's family, especially from her parents and her maternal uncle, to become the boyfriend of their daughter. However, at this stage, legitimised by the ritual of gewi una, the couple may still separate as the woman's family yenuma tuak no kana manuk nawa (literally, have not drunk the local palm or coconut alcoholic juice and eaten the chicken) from the man's family, an act that symbolises the legitimate union between the two clans. According to Bala-Kwasa, "The legitimate union between the two clans begins when the woman's family have drunk the tuak and eaten the chicken of the man's family, and the brideprice has been negotiated" (Bala-Kwasa, interview, July 2000).

After the gewi una ritual, the young couple may get to know each other more in public through an exchange of gifts. Gifts are usually in the form of $i k a t$ or traditional sarongs, or corn flakes provided by the woman herself. From the man, the gift may be the meat of hunted wild animals slain by himself. This exchange of gifts, however, must be carried out by a lala alap or jembatan (mediator). The man and the woman choose this lala alap themselves. The couple should have a good relationship with their lala alap, as the lala alap ensures that the relationship between the couple is positive and runs smoothly. If the first gift is well received, then the next one will be a greater gift in terms of quality and quantity, such as a ring or a bracelet.

When the lala alap finds positive interaction between the couple, they will inform the parents of both sides. The purpose of informing the parents is to determine whether or not they agree with the relationship between "their children." Then, a meeting in the man's family is held to discuss their genealogy and to determine the past relationship between the two marrying clans. The woman and her family's character are also discussed in this meeting. Having approved the relationship, the first delegates to represent the man's family are determined. They then must make an appointment to meet with the woman's family. The meeting between the delegates from both clans begins with the 
offering or exchange of sirih pinang (betel nut) and tembakau (tobacco) prepared by both sides. One of the delegates will begin the discussion by briefly describing the relationship between the future couple. Then, a dialogue between the man's family and the woman's family occurs:

The man's family's representative

kame aka bedi bukan karena keinginan kame sendiri

bukan juga karena kame dipaksa,

tapi karena anak lame kame no lala alap nae

nokanem lala

kame setuju no lalanu dede karena kame

metena suku lamak bedi tempat keme sawi tuak

no ola ma

suku lamak bedi sumber keniki keluok

no tuak wai kame

jadi kame leta kalo ina ama opo alap bisa me negimi

tapu puk tune untuk kama sawi tuak

atau nura newa tune untuk kama ola ma.

(We have come here not because of our own wish or because of being forced, but because of our son and his mediator who has shown us the way. We certainly agree with the way shown to us because this clan is the place for us to find tuak [local palm wine] and the land on which we can work. In short, this clan is our clan's source of food and drink. So we want to ask if we can get a wine tree for producing tuak or a piece of land for our son to work on).

\section{The woman's family representative's reply}

kame taku bisa tapana keniri mio sekarang ale

tedem sampe kame kelalewa tapu puk alap

nura newa alap.

(We cannot answer you directly; but could you please wait until we ask the owner of the pohon tuak [local palm wine tree] and the owner of the land).

After agreement is reached between the two families, the woman is called forward to directly respond to the proposal from the man's family. The man must also express his love for the woman in front of the two families, in order to demonstrate to the parents and delegates of both parties his genuine love. Then, both families share a meal together. The food prepared by the man's family, including meat (chicken and pork) and tuak (local palm alcoholic 
drink), may only be consumed by the woman's family, whereas the food prepared by the woman's family is usually enjoyed together. This occasion of eating together is possible only if there is a positive agreement among all the involved parties. If the positive reply is still to be considered, then the man's family is asked to return to their home with all their food and drinks until they are invited back to the woman's family home for further negotiation.

The ritual acceptance of the proposal by the woman's family is the beginning of the legitimate relationship between the couple, and between the two families. The door to the girl's family home is now open. It means that the girl is now formally engaged and cannot accept a proposal from another man. The man is free to visit and go out with his girlfriend. This gewi una ritual is almost like a "ticket" for the couple to each other's homes. Yet both, especially the man, must be careful with their words and behaviour, as any little mistake may result in adat sanctions. The gewi una ceremony is concluded with the appointment of delegates from both clans, and a time is set for the adat formalisation of the relationship.

The breaking of this legitimate relationship by the man has serious adat sactions for the man's family, because it is considered that he has shamed and disadvantaged the woman. The adat sanctions for the man's family involves giving the woman's family one ivory tusk in order to tutup kenawi una opo alap (to close the door of the woman's family's home) which was opened at the gewi una ritual. The breaking of the relationship by the woman also has adat sanctions, involving the return or repayment of everything given by the man and his family. In Ata Baolangu, the gewi una ritual is not a guarantee that the boyfriend and girlfriend will become a married couple. It is only a ritual to legitimise their relationship. The next ritual ensures a marriage between the couple.

\section{The Sera Kiri Blino Malu Kleruk Ritual}

On the day of the sera kiri blino malu kleruk ${ }^{13}$ ritual (the traditional formalisation of marriage), the man's clan members accompany him in a long procession to the woman's family home. Usually, this ritual occurs in the afternoon. The woman, with one of her female friends, is dressed up in traditional clothes, and stands at the front door of her parent's house to wait for the coming of the man with his clan members. The man comes to the woman's home with a bag of his own clothes, as well as clothes and jewellery for his fiancee, including sandals, hair ornaments, a ring, bracelets, a Bible and rosary beads. The wife-receiving clan brings food, the local alcoholic 
drinks tuak (local palm wine) and arak (strong local spirit made of tuak), betel nut and cigarettes. Traditional drums may be played during the procession. When the man and his family arrive, they stand outside the front door of the woman's house, and a short dialogue occurs between the delegates of both parties. The dialogue is about the purpose of the coming of the wife-receiving clan and the reply and welcome from the wife-giving clan.

The main part of the ritual of sera kiri blino malu kleruk is the exchange of rings between the couple, witnessed by their parents and participants. After the ritual of ring-exchange, the man's family are invited to take a seat under the tarpaulin so that the wife-giving clan can offer them betel nut and cigarettes. The woman must serve the man's entire family, from the parents of her future husband to the youngest sibling of her fiancee. All participants must accept or take what the woman offers. To take what is offered is a symbol of acceptance of the woman into the man's clan. In this ritual, the woman becomes a new member of the man's clan.

Refusing what the woman offers means rejection of the woman herself. This can be very upsetting as it indicates her past mistakes, and signals that she must ask for forgiveness. After the offering of the betel nut, the members of the wife-receiving clan are served coffee or tea, local corn flakes and fried bananas. The two families do not share the main meal; they can only exchange food and drinks to take back home. The food given to the wife-receiving clan by the wife-giving clan is taken back home to be shared among participants. Usually, a lot of food and drink is provided by the wife-receiving clan for the wife-giving clan as a symbol of respect and capability. During this sera kiri blino malu kleruk ritual, the negotiation of brideprice takes place, usually after the exchange of food. When the members of the wife-receiving clan return home, other delegates remain at the woman's family home for the negotiation of brideprice. The bridegroom must also stay at his fiancee's home to help serve the negotiators of belis, the brideprice.

\section{The Negotiation Ritual of Belis}

It should first be noted, the bridewealth discussed during this ritual occasion generally concerns two main types of ivory, including bala tmawil and bala oeng. ${ }^{14}$ They may also negotiate the possibility of an additional ivory tusk for the opo puk (the maternal uncle). This additional ivory, however, depends on the opo puk, and whether or not he wants the brideprice, as he is also obliged to reciprocate. This is called oi blotung. ${ }^{15}$ In Ata Baolangu, the amount and size of ivory also depends upon the number and size of the ivory paid for the mother of the bride to be. Bargaining over the bridewealth during this occasion 
rarely happens, because there is another occasion for this during the occasion of the jin bala ritual (jin means "to see," bala means "ivory"), during which the opo alap (the wife-giving family) is asked by the bine makin (the wifereceiving family) to examine the value of the ivory tusks, and see if they are satisfied with them in terms of size. This negotiation ritual of the bridewealth can potentially lead to heated conversations between the representatives of the two parties. Sometimes the demands from the opo alap may be considered by the bine makin as excessive, but sometimes also what is on offer is considered too little, though never too great. This disagreement can also happen during the occasion of jin oi werat, ${ }^{16}$ and is very common in Ata Baolangu, though it is accepted as part of the negotiation ritual of belis, the brideprice.

The opo alap are also obliged to reciprocate for the bridewealth given by the bine makin. Thus, they should carefully consider their own capability in poi bala (reciprocating). The bridewealth is not given for free. It may be called a gift, but this gift is never a free gift, as per Mauss's formulation, cited in Douglas (1993). The opo alap must give to the bine makin traditional sarongs and large ivory bracelets. Especially for the bala tmawil, the return has to be of exactly equal worth as the ivory tusks, which usually amounts to two traditional sarongs and ten large ivory bracelets. It is different for the bala oeng, for which the return of the bala oeng is up to the generosity and willingness of the opo alap. The return for the bala oeng is called oi peten bine. ${ }^{17}$ Usually, this amounts to one adat sarong and five ivory bracelets.

Clearly, the business of bridewealth in Ata Baolangu involves rights and duties: the right to demand and receive, but also an obligation to reciprocate. It is the right of the opo alap to ask for and receive the ivory but at the same time they know that they must give the man's family the adat sarongs and the bracelets in return. Both parties have rights and responsibilities. In this sense, there should be mutual understanding among them in the process of negotiation. Only after the two parties reach the agreed brideprice, the Catholic wedding day may be set. The customary marriage and the liturgy of the Catholic sacrament of matrimony is a common practice among the Ata Baolangu, and together they form a more complete marriage ritual process. The three customary marriage rituals, as discussed, are in themselves valid and complete in accordance with the local adat system of the Ata Baolangu, but because of the influence of the local Catholic Church, sometimes the customary marriage rituals are considered incomplete without the sacrament of matrimony. Yet due to the scope of the paper, I concentrate only on the practice of customary marriage rituals, with a particular focus on the three key rites. 
Indeed, the negotiation ritual of belis or the brideprice in Ata Baolangu is considered the most pivotal rite in the whole process of marriage. This is also the case among the Ata Lio of central Flores. As John Prior states, "the most decisive step in the whole marriage process is the negotiation of the ngawu: bridewealth" (Prior 1988: 117). The spokespersons of the two clans engage in negotiation for hours or even days until they reach an agreement. Formerly, the whole negotiation was conducted in ritual language, which was full of metaphors. Today, this type of language is used less frequently. However, the oratory and negotiation skills of the clan heads and other representatives remain crucial determinants of the success of a negotiation.

The clan spokespersons must know how to speak well, penua tapan keniri (to speak and respond). This negotiation of the brideprice is, in my view, a contestation and a performance. The opo alap demands a great amount of brideprice, while the bine makin responds to the high demands with a special technique of bargaining. This bargaining can be a lengthy process, and is often very tiring and wasteful in terms of time and resources. The process can be considered excessive and unnecessarily theatrical because there is already an adat consensus on the total amount and size of ivory tusks given as brideprice. So, what is the negotiation all about? The drama, the poetic language, the threats, the tears and the tension are all crucial elements of the negotiation ritual of the brideprice. According to Prior:

This negotiation is not about reducing the brideprice or buying a human being. It is a formal display, an elaborate ceremony that makes the bridewealth palpable to both sides. The tense debate shows how important an affair marriage is, how important (expensive) women are (Prior 1988: 118).

The negotiation skills of both parties also reflect the pride and reputation of their respective lineages.

The marriage negotiations and exchanges are part of a symbolic economy of status. The time, energy, costs and communication skills required in the negotiation of bridewealth can cause difficulty. The negotiation process is often complicated, or delayed by many different factors, including the deliberate absence of certain key stakeholders within the clan, past mistakes of the couple that have not been properly reconciled, and disagreements among certain key people concerning the compatibility of not only the couple but also the two marrying parties: the wife-giving and the wife-receiving clans. My intervewee Bala-Kwasa once explained to me, "The adat business of marriage, especially concerning the discussion of bridewealth, is often very 
tiring and can damage relationships between individual persons and even between clans" (Bala-Kwasa, interview, July 2000). Having explained the ritual stages of the customary marriage among the Ata Baolangu, I shall now explain the symbolic meanings of customary marriage rituals.

\section{The Symbolic Meanings of Customary Marriage Rituals}

I identify two key symbolic meanings of the customary marriage rituals among the Ata Baolangu. They include: marriage rituals as gifts to the local gods, the Lera Wulan Tana Ekan; and a sacred communion. This discussion is important to support my main argument that marriage rituals are necessary to legitimise the relationship between the two parties involved and to ensure legitimate procreation, as well as to strengthen social relations between and within clans, and symbolically to create harmony between the two worlds - of the living and the dead.

\section{Marriage Rituals as Gifts}

Marriage rituals among the Ata Baolangu are commonly viewed as gifts made to the Lera Wulan Tana Ekan and the ancestral spirits. Tylor identified rituals with gifts made to the soul of a person or object, or to the spirit of a personified cause (Tylor, cited in Howell 1996); or in Mauss's term, "a gift that compels the deity to make a return" (Mauss, cited in Douglas 1993: ix). The expected return is fertility and solidarity between the profane world and the sacred as well as between the wife-giving and the wife-receiving clan. Mauss claims, "A gift that does nothing to enhance solidarity is a contradiction" (Mauss, cited in Douglas 1993: vii). Mauss then goes on to argue that there is no such thing as a free gift. The gift is a commitment and an obligation to reciprocate. "Do ut des, I give so that you may give" (Mauss, cited in Douglas 1993: ix). The wife-receiving clan who gives the brideprice to the wife-giving clan also receives other things in return. The reciprocity between the two clans in giving and receiving represents the reciprocal gift between the Lera Wulan Tana Ekan and humankind. The sacrifice of pigs, goats and chicken by the bine makin (the wife-receiving clan) for the opo alap (the wife-giving clan), and fish for the bine makin from the opo alap, for instance, symbolise the reciprocal gift. 


\section{Marriage Rituals as a Sacred Communion}

Marriage rituals among the Ata Baolangu can be seen also as a means of legitimising a communion of the marrying couple, and their respective families. The relationship between people regarding the way they address and treat each other especially when the rituals are being conducted is rather formal. The opo alap regardless of age and sex, who are in the superior position, enjoy a special respect and treatment from the bine makin, who occupy the inferior status. However, through marriage the two clans are brought together in communion with each other. They are united, but remain different; and their socio-kinship status is legitimised through the marriage rituals.

In order to effectively legitimise the collective communion, it must be performed correctly at the right time, in the right place, with the right sacrificial animal, and by the right person. In Tana Wai Brama, for instance, Lewis notes:

The ceremonial system of Tana Wai Brama is founded on the rights, perquisites, and obligations of the tana pu'an, the source of the Domain, who is always a man of sukun Ipir and who bears a singular responsibility for the maintenance of the relationships between the people of the domain and the land from which they secure their living. ... In the religion of the people of Tana Wai Brama, the people of Ipir are uniquely related to the land and forest, which is still the abode of the nitu noang. Because of their precedence in the domain, they are also uniquely placed to communicate with the deity, upon whose beneficences depends the protection of human beings from the vengeful nitu noang. Without the intercessions of Nian Tana Lero Wulan, the nitu can afflict humans, their animals, and their crops with disease, infecundity, and failure (Lewis 1996: 113).

In marriage rituals among the Ata Baolangu, domestic animals (such as goats, pigs, and chickens) are sacrificed; because domestic animals are considered as "cold" animals in contrast to wild animals, which are considered "hot" animals. It is believed that heat can cause infertility, illness, failure and even death. In the agricultural context of the Lamaknen community in central Timor, "preparatory to sowing, the seeds of rice or maize must be cooled by means of a ritual at an altar in the fields. A pig, which is considered a "cold" animal, is sacrificed and its blood is used for this purpose" (Friedberg, cited in Fox 1980b: 271). This sacrifice of a pig, on one hand, ensures abundance of harvest, but, on the other hand, and more importantly, it maintains harmonious 
relationship within and between communities - the living and the dead, the profane and the sacred.

The significance of marriage rituals is to maintain harmony, good order and mutuality within and between communities. The customary marriage rituals are thus primarily concerned with social relations, rather than those concerned with individual or personal well-being. Marriage rituals are inclusive rituals, they include all members in the communities, the dead and the living, men and women, young and old. They are community events, and not individual, personal events; they are not exclusive rituals (Howell 1996). This mythical communion between the world of the sacred and of the profane, demonstrated through marriage rituals, is important as it ensures legitimate relationship between the marrying couples and their respective clans, and legitimises procreation.

Having discussed the stages of customary marriage rites and their symbolic meanings, I will now reflect further on the question of how this study of the Ata Baolangu highlights common aspects of rituals and ceremonies that may contribute to a broader understanding of Indonesian and Asian traditions and philosophy. It is hoped that this reflection will stimulate further study on, for example, the cross-cultural understanding of marriage and ritual across the Indonesian archipelago and Asia.

\section{Further Reflection}

Even though the customary marriage rituals of the Ata Baolangu may be distinctive, this study helps one to recognise and understand the commonality of certain aspects of marriage and ritual across Indonesia, and in some cases even Asia in general. I identify five significant themes concerning marriage and ritual including: rituals are very prominent in Indonesia; distinct ancient rituals have been preserved in the face of colonisation, nationalisation, modernisation and religious conversion; marriage is mainly concerned with procreation; rituals and marriage are linked with social status; and marriage rituals involve reciprocity, both between the marrying families and the wider community.

The discussion on the customary marriage rituals of the Ata Baolangu demonstrates how prominent rituals and ceremonies are, not only in the Ata Baolangu of Lembata but also in Indonesia in general. As explained earlier in the paper, societies are largely constructed on, and characterised by, rituals. Rituals and ceremonies are the very identity of the community. As de Coppet argues, "rituals are at the core of the social identity of all communities" (de 
Coppet 1992: 1). A society is shaped by rituals, and rituals strengthen a sense of community (Turner 1969). It is therefore impossible to separate societies from rituals, as suggested by Durkheim (1976 [1912]). While not trying to deny the importance of rituals in the constitution of societal identity and a sense of belonging, it should be noted that rituals, as in the case of marriage rituals among the Ata Baolangu, could arguably become a source of division and inequality of power. Ritually, members of the community have different roles and positions, and are expected to show certain behaviours in order to avoid offence and disrespect to the community of the living and the dead. For example, in marriage affairs, the community is divided into two main groups namely the opo alap (the bride's family) and the bine makin (the groom's family). The bine makin are always subordinate to the opo alap, and this could reflect a sense of inequality in the community. The type of inequality here is not a gender-based one, but is based on kinship.

In a general sense, people are indeed born into a system of rituals and ceremonies, and throughout life different stages are marked by certain rituals and ceremonies. There is a shared belief in the necessity and the power of ceremony and ritual as part of the human experience. In general, ceremonies and rituals help people transition and evolve through life from one state of being to another; it is a passage of life. They allow people to acknowledge growth and change; they create meaning; they make moments truly sacred; and they provide a sense of security and stability to the people who journey through to the next phase of their lives. Ceremonies and rituals also create social connection between people, as well as connection between the world of the living and the dead, as in the case of the customary marriage rituals of the Ata Baolangu. Through ceremonies and rituals, participants are allowed to cocreate the experience of connection and meaning.

As noted, in Ata Baolangu and elsewhere in Indonesia, there are many different rituals including birth rituals, rites of initiation, marriage rituals, rites of the dead and agricultural rituals. These rituals such as Ngaben (cremation ceremony) in Bali, and Rambu Solo (funeral ceremony) in Tana Toraja of South Sulawesi, for instance, are distinct ancient rituals, and have been preserved in the face of colonisation, nationalisation, modernisation and religious conversion. There perhaps are certain aspects of rituals that may have been modified for certain purposes, but arguably their essence and values are believed to remain. These ancient rituals remain to this day because they are viewed to be the very identity of the community; they are an intrinsic part of everyday life, as one can see in Bali where every day without exception, the locals, especially women, perform offering rituals to the deity. 
It should be noted, however, despite appreciation of the symbolic meanings and social functions of rituals in the (re)construction of social identity and unity, ritual practices, as in the case of the Ata Baolangu, can prove to be economically wasteful. Most ritual events, and particularly marriage rituals, indeed require a significant amount of money and costly preparations, often leaving the hosts in debt after the celebration. Partly because of this, the symbolic meanings and values of rituals are sometimes questioned by both the locals themselves and outsiders. The rituals seem to become more like a public display of social status and prestige. Indonesian writer Fanny J. Poyk (2016), in his short story, "Belis Si Mas Kawin," mentions that in the eastern Indonesian island of Rote marriage rituals concerning brideprice are determined by the social status of the woman's/wife's mother and grandmother. The higher the social status the mother and the grandmother has, the more brideprice the man's/husband's family has to give. Poyk writes, "Kau bukan perempuan sembarangan. Perempuan Rote keturunan raja-raja Bilba jika menikah sang suami harus memberikan belis yang bernilai tinggi pula. Kau bukan gadis dari kasta rendahan" (You are not an ordinary woman. When they marry, Rote Women of the line of the Bilba kings must be given a bridprice of high value from their husbands) (Poyk 2016). In this sense, on one hand, the brideprice received by the bride's family is a symbol of the social status and prestige of the bride's family, and on the other hand, for the groom's family, the bridesprice is a symbol of respect and pride. The marriage rituals involve giving and receiving, the marrying families are involved in what could be termed as an exchange of gifts. The idea of reciprocity is essential in marriage as represented in the rituals of giving and receiving of brideprice. This idea of reciprocity can be seen all throughout in Indonesia and elsewhere.

I should note, however, that in recent years there is an increasing number of people of both genders from the Baolangu community who are marrying outsiders. As a consequence of the "mixed marriages" between different ethnic communities, the customary marriage rituals are not performed as rigidly as in the past. Certain rituals and their importance, such as the negotiation ritual of brideprice, are consequently renegotiated and compromised. The rituals are often simplified, and the use of ivory tusks as a brideprice is sometimes substituted with money. On one hand, this could be seen as a positive sign of evolution of ritual forms and practices; it represents people's openness and willingness to remodify certain aspects of rituals to suit the changing needs of their time without necessarily losing the core meanings and values of marriage and rituals. On the other hand, however, some local critics suggest that the remodification of ritual forms and practices pollute the purity of rituals, and 
even condemn it as a sign of "cultural extinction." The important symbols of respect and relationship, such as brideprice are thus predicted to be lost in generations to come. Yet the question is: would the loss of symbols in the community necessarily mean that the values of respect and relationship, which they symbolise, will also be lost?

The last important common element is the correlation between procreation and marriage. In the Ata Baolangu community and elsewhere in Indonesia, marriage is still seen to be associated with procreation. Often foreign people visiting Indonesia are confronted with the question, "sudah punya berapa anak?" (how many children do you have)? This question underlines two interesting assumptions. First, you must be married (and with a person of the opposite sex). Second, you must have children, not just a child, but a few children. A female foreign tourist was once asked, "sudah punya berapa anak?" by a shopkeeper in Indonesia. The tourist became a little upset, and found the question confronting. At first, she did not know how to respond. She felt she would be compromising a little too much of her privacy by answering such a confronting question. However, simply ignoring the question-letting go and getting into the business of enjoying her holiday-was contrary to her nature. She felt that she had to say something in response, and finally she did. The tourist simply told the shopkeeper that she could not answer her question.

The question and the story above demonstrate a traditional notion of marriage in some Indonesian societies. What is marriage? Why do people get married? One is born to one day get married and have children. Of course, an exception applies to Catholic priests and nuns who are required to be celibate. Being born to be married, and to be married to have children, is an expectation that emphasises a particular notion of marriage. Today, this notion or expectation is still strong in Indonesia. Life, marriage and procreation are all intrinsically inter-connected. Life seems to be about marriage, and marriage is about procreation. A marriage without children is not even considered a (successful) marriage, but a "curse" from the ancestors.

In July 2000, I interviewed people in Lembata, about the purpose of marriage. A common response is that marriage is for procreation. People get married to procreate. It is thus considered a taboo, or in the local dialect of Lamaholot glarak, for a married person to say that she or he does not want to have children, according to the comments of an interviewee. In addition, they said that ideally a couple should have sons and daughters, as the sons will guarantee the continuation of the clan, penerus suku (marga), whilst the daughters are the source of brideprice for the wife's family. Interestingly, there was no explicit mention of the aspect of companionship in marriage, which is considered very important by most people in the west. It seems that 
once one is married the focus is chiefly on producing children, and the whole community will wait and see when, not if, the wife will fall pregnant and give birth. Such a close link between marriage and reproduction in villages in Lembata, for example, partly create the circumstance by which many women today fall pregnant before they actually get married. Why? Sex and pregnancy before marriage may be seen as a kind of fertility test, tes kesuburan, as it seems to be considered more embarrassing for a woman and her family to find out after marriage that she cannot fall pregnant, than falling pregnant before marriage. This is an interesting contradiction because there is also an adat sanction or penalty, denda adat, for the family of the man (not necessarily husband-to-be) that impregnated the woman, not to mention the Catholic notion of no sex before marriage. The notion of fertility, in this regard, is often spoken of in direct link with women, not men. This notion of fertility, biological and/or social, would be worthy of further investigation.

Marriage is not an option or a choice but a destiny. It is not a matter of one's individual right but a collective obligation to ensure that everyone in the community is married and produces children. The question, "sudah punya berapa anak?", thus appears not to be an optional but an obligatory question. When one becomes an adult then it is normally expected that one gets married and reproduces. Having one child is not and cannot be enough, there should be more, preferably equally gendered. The experience of many, including the female foreign tourist, of being confronted with such a question illustrates a notion of marriage in Indonesia that one is born to get married and have children. This is a societal expectation.

The notion of the fundamental correlation between life, marriage and reproduction in Indonesia, may be different from other societies elsewhere. In Australia, for example, the birth rate is so low that the Federal Government has been encouraging people (couples) to have children, and the government is prepared to provide financial support. Whatever political reasons the Government may have for the discourse, reproduction in Australia remains an important guarantee for the continuation of the country, to prevent the phenomenon of "the aging population" and a reliance on immigration to fill the space and needs of Australia. This fact highlights the contrast between Australia and Indonesia, two neighbouring countries that are at the opposite ends of the reproduction spectrum. Indeed, in Indonesia, marriage and procreation are an inseparable entity, and this entity feeds the societal expectation, and hopefully signifies the continuation and prosperity of the community. Can this constructed inseparability be reconstructed in the endeavour to tackle the growing population in Indonesia? In addition, will people in Indonesia forever ask a new acquaintance, "sudah punya berapa anak?" 


\section{CONCLUSION}

In this paper, I have explored the meanings, practices and contexts of marriage and ritual among the Ata Baolangu of Lembata, Eastern Indonesia. Employing the methodology of qualitative field research conducted by interviewing local stakeholders and by participation in, and observation of, local community life, the paper argued that all of the customary marriage rituals are necessary to ensure a legitimate relationship between the two parties involved and procreation, the maintenance and transformation of social relations between and within clans, and the creation of harmony between the two worlds - of the living and of the dead. In explaining the main proposition of the paper, I began with an examination of concepts of ritual and marriage. I then examined the customary marriage rituals among the Ata Baolangu, in which I identified three main stages of rites and two key symbolic meanings of the rituals.

As discussed, marriage is fundamentally associated with rituals and procreation. This suggests that procreation alone is insufficient to fully satisfy the community. The children born from the marriage have to be legitimate, and ideally are of both genders in order to maintain the socio-cosmic balance. The idea of procreation, legitimacy and fertility are all important in the business of marriage. In order to ensure legitimate procreation and gender balancedprogeny, customary marriage rituals are performed. I have identified three main rituals including the ritual of gewi una (entering the woman's family home), the ritual of sera kiri blino malu kleruk (the traditional formalisation of marriage), and the negotiation ritual of belis, or the brideprice. All of these three stages of rites must be completed in the correct order for them to be effective in their procreating and legitimising roles. I have also identified two key symbolic meanings of the customary marriage rituals among the Ata Baolangu. They include: marriage rituals as gifts to the local gods, the Lera Wulan Tana Ekan; and marriage rituals as a sacred communion. The identification of these two symbolic meanings is important to support the primary argument of the paper.

In this context, I have paid particular attention to the negotiation ritual of brideprice, or belis. The discussion of bridewealth is considered a major negotiation ritual among the Ata Baolangu, as it is believed that successful negotiations ensure smooth socio-cosmic relations. Ivory as a brideprice is not merely a material possession, but is a phallic symbol given by the bine makin (the wife-receiving family) to the opo alap (the wife-giving family). In return, the opo alap also must give the bine makin something back, for example, traditional sarongs and ivory bracelets. Brideprice is also viewed as 
a symbol of status and prestige within the society. The business of brideprice involves rights and duties, the right to demand and receive, but these rights also imply an obligation to reciprocate. Giving and receiving in the marriage ritual context of the Ata Baolangu is an obligation. The two marrying clans are obliged to give and receive, but nothing is free. No gift is a free gift, as stated by Mauss, and cited in Mary Douglas (1993).

Finally, this paper has also identified five common themes of marriage and ritual across Indonesia. They include, as explained in the following. First, rituals are very prominent in Indonesia. Second, distinct ancient rituals have been preserved in the face of colonisation, nationalisation, modernisation and religious conversion. Third, marriage is mainly concerned with procreation. Fourth, rituals and marriage are linked with social status. Fifth, marriage rituals involve reciprocity, both between the marrying families and the wider community.

\section{ACKNOWLEDGEMENTS}

This paper is the result of field research conducted through interviews and discussions with, as well as through participation in the community life of, the indigenous Ata Baolangu community in Lembata, Eastern Indonesia over a long period of time. My field research was undertaken in the Ata Baolangu community. I would thus like to acknowledge those who shared their ideas and experiences with me concerning the meanings, practices and contexts of marriage and ritual in their community. I sincerely thank my interviewees for their generous time and stories that have helped give substance to my paper.

\section{NOTES}

* Justin L. Wejak currently teaches the Indonesian Language and Studies Program at the University of Melbourne, Australia. He completed his first undergradutate degree in Philosophy at the School of Philosophy in Ledalero, Maumere, Flores (Indonesia), and his second degree in Theology was undertaken at Melbourne College of Divinity (now The University of Divinity). He then studied for his Master of Arts (Anthropology) at The University of Melbourne. He completed his $\mathrm{PhD}$ at the same university, writing on the culture of fear concerning the political upheavals of 1965 in Indonesia.

1 For the scope and purpose of this paper, I do not intend to provide a long and detailed ethnography of the community studied, but just a brief mention about its location, livelihood and religion. 
2 In terms of languages spoken on the island of Lembata and the neighbouring islands such as Flores, Adonara, Solor, Alor and Pantar, refer to Adelaar and Prentice (1996), Fernandez (1977) and Fox (cited by Graham 1991). Concerning political history of Lembata, refer to Wolor (2006), and Burin (2004).

3 The names of people interviewed cannot all be identified in this paper, for reasons of confidentiality.

4 For comparisons, refer to data collected by J. J. Fox on "comparative research in Eastern Indonesia" (Fox 1980a, 1980b), Douglas Lewis on "Tana 'Ai” (Lewis 1988), Penelope Graham on "a Domain of Eastern Flores" (Graham 1991) and "Issues in Social Structure in Eastern Indonesia" (Graham 1985), R. H. Barnes (1968, 1974, 1980a, 1980b), and John Mansford Prior on "Church and Marriage in an Indonesian Village" (Prior 1988).

5 A revised version of this minor thesis has been published in a book chapter. For this, see Justin L. Wejak (2015), "Mitos Asal Usul Padi di Flores, Indonesia Timur" (The Myths of Origin of Rice in Flores, Eastern Indonesia), in Pemburu Yang Cekatan (Skillful Hunter), eds. Julian Lee et al. (Ledalero: Penerbit Ledalero). The English version of the article was also published in 2016 in the United States as a chapter in a book (Wejak 2016).

6 Lera Wulan Tana Ekan is the name for God in the Lamaholot society of East Flores and the islands of Adonara, Solor, Lembata, Alor and Pantar $($ Lera $=$ sun, Wulan $=$ moon, Tana Ekan = earth, land. Lera Wulan are classified as Langit which means sky = male symbol, and Tana Ekan means earth, land = female symbol). The idea of God among the Lamaholot society includes both the male and female elements of God: God the Father and God the Mother. The idea of Lera Wulan Tana Ekan includes the ancestor spirits.

7 Opo puk in the local dialect of Baolangu refers to the brother of the bride's mother (bride's maternal uncle) and the brothers of the bride's and the bridegroom's grandmothers (maternal great uncles). The term opo is a formal title for the bride's mother's brother and the brothers of the bride's and the groom's grandmothers, and is then addressed as opo. The word puk means primary or main. The people referred to by the term opo puk are viewed as the source of life and fertility, and are also believed to be the silent representatives of God, and often even thought to be Tuhan (Allah) Kedua, which literally means "the second God."

8 The word Lewotana is a Lamaholot word referring to the sense of community or belonging. Etimologically, the term Lewotana comes from two words, lewo means village, and tana means land. The term Lewuenaj is a local Baolangu word referring to the same sense of community and belonging, and it comes from two words, lewu $(o)=$ village, and enaj $=$ tana $=$ land. The expressions of Lewotana and Lewuenaj are used to also mean the place or land of origin.

Since the Ata Baolangu is a patrilineal society, the wife to be, must take up her husband's family and clan name, and the children born from the marriage must also use their father's family/clan name. Usually, they have three names which consist of a Christian name, a middle name usually after a grandmother or a grandfather, and a clan name.

9 I was told of the story by the young man himself on 10 November 2017 during my home visit in the village. Some of the young man's siblings also told me the same story. At first, I thought they were making up the story just to tease each other about their past; 
but then I realised that it was a real experience encountered by the young man. Please note, the identitiy of the young man is not specified here for confidentiality reasons, and to avoide possible social akwardness and embarrasment particularly to the young man himself and his family.

10 Most people in the village know the couple who were involved in the incestuous relationship. I heard the story during my upbringing in the village. I recall that my mother once told me about the couple in a shameful tone. Maybe because of a sense of social shame, my mother as well as others did not seem willing to talk in great detail about the couple. The locals even regarded this incest as an accident; it is really not common at all in the village and the surrounding local communities. Despite the rarity of incest, however, there is, as reported by some Indonesian media outlets such as Jawa Pos (Mufid 2017) and Kompas (Buol 2013), a small ethnic group in the northern part of the island of Sulawesi, called Suku Polahi, that has been practising incest for a very long time. The word Polahi, in the local Gorontalo language, means pelarian in Indonesian which means "escapee" or "refugee." It is noted, the people of Polahi ran away to the jungle in the 1700s because they were opposed to the gold tax (pajak emas) applied by the colonial Dutch. They then remained in the jungle of the Province of Gorontalo, Sulawesi, until today. Probably because of remoteness they have been married to each other within the same family. More research, however, needs to be done to obtain more information and details about the practice of incest among the people of Polahi, and particularly how the practice influences the social structure and relations within the community.

11 Mauss's original piece titled Essai sur le don was, as noted, first published in French in 1925. The book was later republished in French in 1950, and its English version produced by Ian Cunnison was published in 1954, and another version in English translated by Wilfred Douglas Halls in 1990. This paper refers to the English version published by Routledge; see M. Mauss (1993).

12 The idea of brideprice (belis) in Ata Baolangu will be discussed in more detail when explaining the key stages of customary marriage rituals, particularly in the subsection of the negotiation ritual of belis (brideprice).

13 The word sera means "to give, to offer"; kiri means "comb"; blino means "mirror"; malu kleruk means "betel nut."

14 Bala tmawil and Bala oeng (bala means ivory, tmawil means to bind, oeng means free or gratis). So Bala tmawil means the ivory to bind, and Bala oeng means the free ivory.

15 Everything that is given to the opo puk (the uncle) of the woman or the brother of the woman's mother must be returned in different forms by the woman's uncle (opo puk).

16 The jin oi werat is the ocassion for the bine maki or the man's family to inspect the items given by the woman's family in return to the brideprice for the opo alap or the woman's family.

17 The oi peten bine is a return for the bala oeng to the man's family as a symbol of love from the woman's family for their daughter who leaves the family for the man's family. 


\section{REFERENCES}

Adelaar, K. A. and Prentice, D. J. 1996. Malay: Its history, role and spread. In Atlas of languages of intercultural communication in the Pacific, Asia and the Americas, eds. Wurm, S. A., Muhlhausler, P. and Tryon, D. T. Berlin: Walter de Gruyter \& Co.

Barnes, R. H. 1968. An ethnographic survey of Lomblen and neighbouring islands, Eastern Indonesia. Undergraduate diss., University of Oxford, Oxford.

. 1974. Kedang: A study of the collective thought of an Eastern Indonesian People. Oxford: Clarendon Press.

1980a. Concordance, structure, and variation: Considerations of alliance in Kedang. In The flow of life, ed. Fox, J. J. Cambridge, MA: Harvard University Press. .1980b. Marriage, exchange and the meaning of corporations in Eastern Indonesia. In the Meaning of marriage payments, ed. Comaroff, J. L. London: Academic Press.

Barnard, A. and Spencer, J. (Eds.). 2000. Encyclopedia of social and cultural anthropology. London and New York: Routledge.

Buol, R. A. 2013. Polahi dan cerita mistis yang melingkupinya [The Polahi and their mystic stories]. Kompas, 7 May.

Burin, K. K. 2004. Sejarah perjuangan otonomi kabupaten Lembata [The history of the struggle for autonomy of the Lembata Regency]. Surabaya: Penerbit PERUM Percetakan Negara RI Surabaya.

Cowie, A. P. (Ed.). 1989. Oxford advanced learner's dictionary of current English, 4th ed. Oxford: Oxford University Press.

de Coppet, D. (Ed.). 1992. Understanding rituals. London: Routledge.

Douglas, M. 1993. The gift, trans. Halls, W. D. London: Routledge.

Durkheim, E. 1976 [1912]. The elementary forms of the religious life, trans. Swain, J. W. London: George Allen and Unwin.

Fernandez, I. Y. 1977. Bahasa lamaholot ile mandiri. Postgraduate diss., Universitas Gadjah Mada, Yogyakarta.

Fox, J. J. (Ed.). 1980a. Comment on early Austronesian social organization: The essence of language, by R. Blust. Current Anthropology 21 (2): 205-247. .1980b. The flow of life: Essays on Eastern Indonesia. Cambridge, Mass.: Harvard University Press.

Geertz, C. 1973. Interpretation of cultures. New York: Basic Books.

Graham, P. 1985. Issues in social structure in Eastern Indonesia. Master diss., University of Oxford, Oxford.

1991. To follow the blood: The path of life in a domain of eastern Flores, Indonesia. $\mathrm{PhD}$ diss., Australian National University, Canberra.

Howell, S. (Ed.). 1996. For the sake of our future: Sacrificing in Eastern Indonesia. Leiden: Research School CNWS, Leiden University.

Kertzer, D. I. 1988. Ritual, politics, and power. New Haven and London: Yale University Press.

Levi-Strauss, C. 1969 [1949]. The elementary structures of kinship. London: Eyre and Spottiswoode. 
Lewis, E. D. 1988. People of the source: The social and ceremonial order of Tana Wai Brama on Flores. Dordrecht, Holland and Providence, Rhode Island: Foris Publications. https://doi.org/10.1017/s0041977x00151973

1996. Invocation, sacrifice, and precedence in the Gren Mahe Rites of Tana Wai Brama, Flores. In For the sake of our future, ed. Howell, S. Leiden: Research School CNWS, Leiden University.

Making, Y. 2013. Asal usul suku di Pulau Lembata [The origins of the people of Lembata]. Flores Bangkit, 3 October.

Mauss, M. 1925 [1993]. The gift: Forms and functions of exchange in archaic societies. London: Routledge.

Müller, K. 1997. East of Bali from Lombok to Timor. Singapore: Periplus.

Mufid, J. S. 2017. Mengunjungi suku Polahi dengan tradisi inses di pedalaman Gorontalo [Visiting the people of Polahi in Inner Gorontalo who have an incest tradition]. Jawa Pos, 24 July.

Poyk, F. J. 2016. Belis si mas kawin [The brideprice]. Kompas, 10 January.

Prior, M. J. 1988. Church and marriage in an Indonesian village. Berlin: Verlag Peter Lang.

Rahner, K. (Ed.). 1986. Encyclopedia of theology: A concise Sacramentum Mundi. London: Burns \& Oates.

Turner, V. 1969. The ritual process: Structure and anti-structure. Chicago: Aldine.

Wejak, J. L. 1998. The mythical origins of sacrificial rituals of 'Rice Mother' in Flores, Eastern Indonesia: An anthropological study. Minor thesis, Department of History and Philosophy of Science, Faculty of Arts, University of Melbourne.

2015. Mitos asal usul padi di Flores, Indonesia Timur [The myths of origin of rice in Flores, Eastern Indonesia]. In Pemburu yang cekatan [Skillful hunter], eds. Lee, J. and Prior, M. J. Ledalero: Penerbit Ledalero.

2016. Myths of origin of rice in Flores, Eastern Indonesia (183-198).

In Trajectories: Excursions with the anthropology of E. Douglas Lewis, eds. Lee, J., Prior, M. J. and Reuter, T. A. New York: Peter Lang.

Wolor, M. (Ed.). 2006. 5 tahun otonomi Lembata [Five years of the autonomy of Lembata. Makassar: Percetakan Mandiri Cards. 